\title{
REVIEW
}

\section{Energy Flow in a Tidal Flat Ecosystem}

\author{
B. R. Kuipers, P. A. W. J. de Wilde and F. Creutzberg \\ Netherlands Institute for Sea Research, Postbox 59, Den Burg-Texel, The Netherlands
}

\begin{abstract}
This review considers the energy flow through a tidal flat ecosystem in the western Wadden Sea. Based on available estimates of primary production, input of allochthonous organic matter, as well as on consumption and production at different trophic levels, a modified concept of energy flow is advanced. In the traditional concept the secondary level has mainly been quantified in terms of herbivorous macrobenthos with an apparently excessive primary food supply, and with the higher trophic levels being food-limited. In our opinion, the importance of small and very small zoobenthos with a negligible biomass, but with a relatively high production, has hitherto been underestimated. This complex - in this review referred to as 'small food web' - consists, in addition to bacteria, of microfauna, meiofauna, temporary meiofauna and small macrofauna. In our opinion these groups contribute far more to the consumption of primary food and to the production of food for small carnivores than is generally assumed in food-chain studies conducted in the western Wadden Sea.
\end{abstract}

\section{INTRODUCTION}

In the temperate zone most estuarine habitats are characterized by strong daily and seasonal fluctuations in oxygen saturation, temperature and salinity, and by pronounced tidal movements. Nevertheless, estuarine habitats are generally highly attractive to animal life: relatively large amounts of solar energy input to exposed mud flats, together with a high availability of nutrients through mineralization lead to considerable rates of primary production. In addition, estuaries with extensive mud flats and banks receive energy input in the form of suspended organic material from the open sea by tidal currents (De Jonge and Postma, 1974). Since pelagic primary production in such estuaries is mainly restricted to tidal inlets and channels (Cadée and Hegeman, 1974a, 1974b, 1979) and since grazing by zooplankton is assumed almost to counter-balance this pelagic production, the following considerations are mainly restricted to the benthic part of the tidal mud-flat ecosystem.

In terms of biomass, tidal flat systems are dominated by dense populations of macrobenthic animals. In North Sea estuaries these include the bivalves Mytilus edulis, Mya arenaria, Cerastoderma edule, Macoma balthica, and the worms Arenicola marina, Lanice con- chilega and Nereis diversicolor (Beukema, 1976). An explanation for this abundance is found in the high availability of food for the restricted number of species that can tolerate these stress conditions. The large mass of invertebrates, in turn, attracts a variety of carnivores such as birds and demersal fishes.

There is little or no fossilization of organic material in the system, and organic matter remaining at successive levels of the food web is usually thought to be mineralized in the sediment by an active bacterial system (De Jonge and Postma, 1974; Beukema, 1976, 1977). In the anaerobic sediment layers of the tidal flats this is effectuated by the typical sulphate reducers (Vosjan, 1975).

Estuaries are usually considered ecosystems of special interest and data on numbers, biomass and to a lesser extent on productions and consumptions at the trophic levels mentioned have been collected in many countries. For the tidal flat system of the western Wadden Sea relevant data are summarized in Table 1.

If the available data are presented in a flow diagram (Fig. 1a) some interesting generalizations can be made. The annual secondary production $(10.8 \mathrm{~g} \mathrm{C}$ $\mathrm{m}^{-2} \mathrm{y}^{-1}$ ) is very low compared to the mass of food potentially available ( $\left.350 \mathrm{~g} \mathrm{C} \mathrm{m}^{-2}\right)$. This had led to the conclusion that macrobenthic populations are limited 
Table 1 Biomass, production and consumption at different trophic levels, partly based on unpublished NIOZ reports. All values expressed as yearly averages in $\mathrm{g} \mathrm{C} \mathrm{m}^{-2}$ Conversion of ash-free dry weight (AFDW) into $C$-weights according to Steele (1974)

\begin{tabular}{|c|c|c|}
\hline \multicolumn{3}{|c|}{ Primary food supply } \\
\hline Detritus input & 250 & De Jonge and Postma (1974) \\
\hline \multicolumn{3}{|c|}{ Phytobenthos } \\
\hline production & $100 \pm 40$ & Cadée and Hegeman $(1974 b)$ \\
\hline Total & 350 & \\
\hline \multicolumn{3}{|c|}{ Macrobenthos } \\
\hline Consumption & 90 & De Jonge and Postma (1974) \\
\hline Biomass & 10.8 & Beukema (1976) \\
\hline Production & 10.8 & Beukema (1976) \\
\hline \multicolumn{3}{|l|}{ Carnivores } \\
\hline \multicolumn{3}{|l|}{ Consumption } \\
\hline plaice & 2.1 & Kuipers (1977); De Vlas (1979) \\
\hline flounders & 0.4 & De Vlas (1979) \\
\hline gobies & 0.5 & NIOZ report (1976-9; 1977-9) \\
\hline shore crabs & 0.6 & $\begin{array}{l}\text { Klein Breteler (1976); NIOZ } \\
\text { report (1980-4) }\end{array}$ \\
\hline shrimps & 0.7 & NIOZ report (1980-3) \\
\hline birds & 2.0 & Hulscher (1975); Swennen (1975) \\
\hline Total & 6.3 & \\
\hline
\end{tabular}

in general by physical factors rather than by food supply (Beukema, 1976, 1977).

However, experiments show that growth in macrobenthic invertebrates in the field may be fooddependent: In Arenicola, for instance, under laboratory conditions growth rates are considerably higher than in the field (de Wilde and Berghuis, 1979). In contrast the carnivores reveal a somewhat opposite trend. In total, the standing stock of secondary producers seems to provide sufficient food to the carnivores. However, a considerable share of the secondary biomass - about one third - consists of deep-burrowing individuals of Mya arenaria and Arenicola marina, i. e. prey items available only to a very limited extent. From the remaining biomass the secondary production (about $7.2 \mathrm{~g} \mathrm{C} \mathrm{m}^{-2}$ ) is also not entirely available to carnivores because the macrobenthos shows an individual weight reduction (up to $50 \%$ of the annual production) from the end of the summer through autumn and winter (Beukema, 1974). The balance, therefore, between secondary production and consumption by carnivores seems rather delicate. This, however, is not in accordance with experimental results on growth in young flatfish: growth rates comparable to those observed on tidal flats in the Wadden Sea were, in the laboratory, only obtained under ad lib. feeding conditions at optimal temperatures (Fonds, 1979). There is, indeed, an additional food source through the production of regenerating body parts such as siphons of Macoma and posterior segments of Arenicola. At times this food source dominates the diet of young flatfish (Kuipers,
1973). Nevertheless, this form of secondary production does not change the food situation of carnivores considerably (de Vlas, 1979).

Thus, the simplification of a productive estuarine system like the Wadden Sea as being a food chain of mainly primary producers, herbivorous macrobenthos, carnivores and bacteria leaves us with the problem that this macrobenthos, strongly dominant in biomass, consumes a surprisingly small share of the total primary food supply, whereas it produces less than should be expected on basis of data concerning consumption by the carnivore level.

This review discusses a possible solution to the problem, based on the consideration that in the tidal-flat ecosystem of the Wadden Sea the herbivorous link between primary producers and higher trophic levels consiss only to a limited extent of macrofauna components. It will be argued that the animal groups in the size range between macrobenthos and bacteria, more or less negligible in terms of biomass, must have an important function in this food web.

\section{ALTERNATIVE ENERGY FLOW ROUTES}

While the estimates on biomass, production and consumption in Table 1 seem to be reliable - but at the same time do not fit satisfactorily into the traditional scheme (Fig. 1a) - an alternative and more complicated flow diagram is suggested (Fig. 1b). In this alternative diagram, groups like micro- and meiofauna, as well as small macrofauna elements have a much more pronounced function in the food chains than is generally accepted on the basis of their almost negligible biomass.

\section{Micro- and Meiofauna}

Several authors (Thorson, 1966; Carey, 1967; Fenchel, 1969, 1978; Gerlach, 1971, 1978) have emphasized the importance of micro- and meiofauna for the energy flow through the benthic system. These groups are defined by mesh-sizes that separate them from the macrofauna and from each other (Perkins, 1974) or by the body-weight categories (Fenchel, 1978); in general, micro- and meiofauna are considered to comprise the group of organisms that passes through 0.5 or $1.0 \mathrm{~mm}$ mesh sizes, while microfauna alone passes through 0.04 to $0.1 \mathrm{~mm}$. The biomass of these categories in the natural sediment is low when expressed as a percentage of macrobenthos biomass at the same positions: 3\% (Sanders, 1960), 6.6\% (McIntyre, 1961), $4.2 \%$ (Wigley and McIntyre, 1964). Densities on the other hand, reach values of up to many 

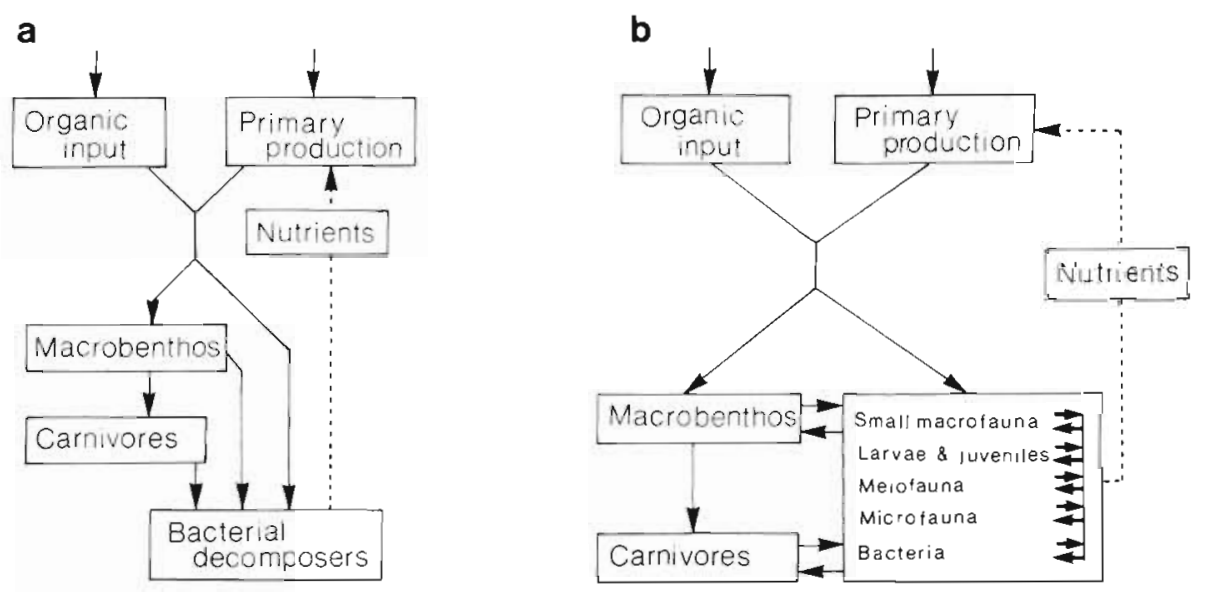

Fig. 1. (a) Benthic food web of tidal flat, illustrated as simple chain of primary food supply - secondary producers - carnivores, with bacteria as balancing link. (b) 'Small food web' incorporated into the flow diagram of Fig. 1a. In both diagrams $\mathrm{CO}_{2}, \mathrm{DOC}$, and inert organic matter, as well as losses through yield and migration are omitted

millions $\mathrm{m}^{-2}$, especially in muddy sediments. For extensive reviews see Thorson (1966), Fenchel (1969), Gerlach (1971) and Perkins (1974).

According to the basic principle that metabolism is a function of body surface rather than of body weight, Fenchel (1969) expressed metabolism in different size categories of organisms in the bottom community of different Danish bays as $K \sqrt[3]{W^{2}}$ where $W=$ body weight. According to that logic, the total group of organisms smaller than $10^{-5} \mathrm{~g}$ body weight appeared to consume about as much, or more, than the rest of the total bottom community, even in a bay with an extremely rich macrofauna $\left(10^{4}\right.$ ind. or $230 \mathrm{~g} \mathrm{w} . \mathrm{w}$. $\mathrm{m}^{-2}$ ). The weight exponent of 0.666 is of crucial importance in these calculations and, compared to that used by other authors, rather low. According to calculations by Günther and Guerra (1955) on biological similarities, a weight exponent of 0.73 holds for large groups of organisms like mammals, amphibia, or reptiles, while Hemmingsen (1960) considered 0.75 to be universal among larger organisms. Banse et al. (1971) give values of 0.71 and 0.73 for crustaceans, 0.72 and 0.81 for bivalves and 0.63 for polychaetes. Warwick and Price (1979) calculated weight exponents for the much smaller nematodes. Based on measurements in several species they concluded that an average exponent of 0.75 applies well to groups of nematode species. Thus it seems reasonable to compare metabolism of macrofauna to that in, for example, of nematodes in the western Wadden Sea on basis of a weight exponent 0.75 .

According to Beukema (1976) the 7 dominating macrobenthic species have a total number of 242 ind. $\mathrm{m}^{-2}$, with an average biomass of $24.4 \mathrm{~g}$ AFDW, the average individual weight of one invertebrate being $0.10 \mathrm{~g}$ AFDW. The meiofauna, on the other hand, has an

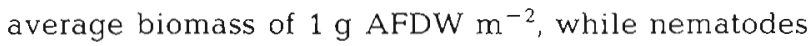
with a density of $2 \times 10^{6}$ ind. $\mathrm{m}^{-2}$ predominate. The average individual weight of a nematode in the Wad- den Seas' tidal flat system is $0.5 \times 10^{-6} \mathrm{~g}$ AFDW (J. Y. Witte, pers. comm.).

While the body weights of a macrobenthic invertebrate and a nematode have a ratio of $200,000: 1$, their individual metabolisms have (according to $R=$ a $W^{075}$ ) a ratio of $9457: 1$ - which means that the nematode, in this example, has a 21 times higher metabolic rate than the macrobenthic individual. When the factor $a$, on which the ratio depends to a certain degree, is left out of consideration, it appears that $1 \mathrm{~g}$ of nematodes in the benthic system consumes an amount of organic material of the same order as that consumed by the total macrofauna. For a sublittoral silty sand community, Gerlach (1971) estimated the share of meiobenthos in the consumption and production of food at $15 \%$ of that of a macrofauna with more than $97 \%$ of the total biomass. Fenchel (1978) came to much higher figures on the importance of micro- and meiofauna, accounting for $41 \%$ of total community metabolism in the sandy sublittoral, and for $69 \%$ and $97.5 \%$ in estuarine sediments and the exposed beach zone respectively.

One possible approach in quantifying the share that different categories, like macrobenthos and micro- and meiofauna and bacteria have in the mineralization of primary food in the benthic ecosystem is the measurement of in situ oxygen consumption in the seabed. Based on such measurements in Long Island Sound, Carey (1967) concluded that the metabolism of macrofauna accounts for only a small part of the total oxygen uptake. Two species of macrobenthic invertebrates (Nephtys incisa and Nucula proxima) together constituting $58 \%$ of the total benthic biomass, are responsible for only $3.4 \%$ of the total average sediment respiration. The author concludes that the meiofauna, microfauna and bacteria must utilize the major portion of the energy consumed by the bottom ecosystem. In comparable marine habitats, macrofaunal respiration varies between 2 and $34 \%$ of total 
community respiration (Pamatmat, 1968, 1977; Banse et al., 1971; Smith et al., 1972; Smith, 1973; Davies, 1975)

Studies on in situ oxygen consumption in the sediment of Wadden Sea tidal flats are in progress; preliminary results show that the macrofauna has a maximal share of $20-30 \%$ in the total community respiration (De Wilde and Berghuis, unpubl.). This percentage is in agreement with the share of $90 \mathrm{~g} \mathrm{C}$ out of the total of $350 \mathrm{~g} \mathrm{C} \mathrm{m}^{-2}$ consumed by macrobenthos $\mathrm{y}^{-1}$. If we assume a food conversion efficiency of only $10 \%$ in groups like micro- and meiofauna and bacteria, the consumption of the remaining $260 \mathrm{~g} \mathrm{C} \mathrm{m}^{-2} \mathrm{y}^{-1}$ would lead to the production of $26 \mathrm{~g} \mathrm{C}$ of body tissue in these groups, or $65 \mathrm{~g} \mathrm{AFDW} \mathrm{m} \mathrm{m}^{-2} \mathrm{y}^{-1}$ of secondary production. Since the average biomass of the meiofauna is ca $1 \mathrm{~g} \mathrm{AFDW} \mathrm{m}^{-2}$, and since bacteria and microfauna cannot add much to this figure, the group as a whole must have a very high $P / B$ ration.

Considering that in the Wadden Seas' benthic system the small organisms discussed here produce as much as $65 \mathrm{~g} \mathrm{AFDW} \mathrm{m}^{-2} \mathrm{y}^{-1}$ of body tissue, the question arises how its total average biomass can stay at the very low level of ca $1 \mathrm{~g} \mathrm{~m}^{-2}$. An explanation for this apparent contradiction was already given by Thorson (1966) and Fenchel (1969) in the complex trophic structure within this group, that consists only to a very limited extent of 'harmless detritus feeders'. In a detailed study on the food web in the sublittoral and estuarine sand microbiocoenosis Fenchel documented that ciliates feed on diatoms, but to an equal extent also on other ciliates, flagellates, and bacteria. Among the meiobenthic organisms described by Thorson even more pronounced carnivores are found; he lists, for example, turbellarians, nematodes, harpacticoids and even foraminifera as 'voracious predators'. When micro- and meiobenthos include such carnivores in successive trophic levels, we would have a food web, in which most of the body tissue produced would be eaten and respired by a very small biomass. In contrast to the macrofauna, which accumulates body tissue to a considerable amount of secondary biomass, the microand meiofauna food web as a whole would produce mainly heat and release nutrients.

\section{Temporary Meiofauna}

Another group in the size range between bacteria and macrofauna is that of the young, newly settled stages of macrobenthic invertebrates, that belong temporarily to the size category of the meiofauna. In 1979 , in a sheltered area of the westem Wadden Sea, the total number of newly settled juvenile macrofauna organisms, retained by a $400 \mu \mathrm{m}$ sieve surpassed 150,000 ind. $\mathrm{m}^{-2}$ (De Wilde, unpubl.). Thorson (1966) estimated the total number of ind. $\mathrm{m}^{-2}$ settling in a sandy bottom Venus community at 120,000 or more in the course of a year. Comparable figures have been reported from the Danish Wadden Sea (Perkins, 1974). According to Thorson, only about $1.4 \%$ or less will grow to sizes retained by a $2 \mathrm{~mm}$ mesh opening; the rest being killed by 'harmless detritus feeders' and the predaceous elements of the meiofauna. Hence, most of the biomass produced by these tiny bivalves, worms and crustaceans during their short life is respired again in meiobenthos food chains.

Although larger in size than meiofauna and meiofaunal stages, the smaller members of the true macrofauna may also be involved in the trophic complex of small organisms discussed so far. According to Beukema (1976), 41 benthic macrofauna species are found on the tidal flats of the Dutch Wadden Sea. Of these only some 6 species account for more than $90 \%$ of the total macrozoobenthic biomass of $27 \mathrm{~g} \mathrm{~m}^{-2} ; 35$ species constitute the remaining $10 \%$. The average P/ $\mathrm{B}$ ratio for the whole group is assumed to be 1 ; hence, the annual secondary production in macrobenthos on the tidal flats is estimated at $27 \mathrm{~g}$ AFDW $\mathrm{m}^{-2} \mathrm{y}^{-1}$. A $\mathrm{P} / \mathrm{B}$ ratio of 1 or less than 1 may be realistic for the larger members of the group, like adults of Arenicola marina or the dominating bivalves; small-sized macrofauna representatives, such as Hydrobia ulvae, Corophium volutator or the group of small polychaete worms (e. g. Scoloplos, Heteromastus) are possibly much more productive than their low biomass suggests. Furthermore, the small-sized macrobenthic species listed by Beukema (1976) are certainly not all true secondary producers (algal-detritus feeders). Detritus feeding in meiofauna was described by Thorson (1966) as follows: in nearly all cases examined, this detritus is collected by the feeding animals from the very surface of the bottom, i. e. from the layer where the newly settled young of the macrofauna will establish themselves after having metamorphosed and left the plankton. It thus seems reasonable to assume that this unsorted detritus will contain at least in certain seasons large quantities of such newly settled young which, therefore, automatically will pass the digestive tract of these non-selective detritus feeders'. In small macrobenthic detritus feeders the same logic will hold: in this group not only newly settled stages of different species but also meiofauna, microfauna and bacteria will be consumed with the unsorted detritus.

The arbitrary division of the benthic fauna in microand meiofauna on the one side and small macrofauna on the other thus seems to cut through a trophic structure that in our opinion should be regarded as one functional whole. 


\section{THE SMALL FOOD WEB}

When bacteria, microfauna, meiofauna, temporary meiofauna and small macrofauna elements in the benthic system are regarded as one complex, this is characterized by the small size of individuals, a high turnover rate, relatively short life spans, and a complicated trophic structure. Especially the latter may explain why in this complex - which we refer to as the 'small food web' - no significant biomass is accumulated. Whereas this 'small food web' in Wadden Sea tidal flats consumes $70-80 \%$ of all organic material available, at each step of the food chains, running in all directions through the web, most of the material consumed is respired.

The 'small food web' is incorporated in the energy flow diagram of the estuarine benthic system in Fig. 1b. This diagram has several new features.

Firstly, it offers a possible explanation for the low macrobenthic productivity. Macrobenthos - consuming only about $25 \%$ of all organic material available is actually a side-track in the main energy flow (or rather C-flow) through the mud flat system (Fig. 2). This view is in accordance with results of the in situ respiration measurements mentioned earlier. As suggested in the flow diagram (Fig. 1b), macrobenthos may compete with the 'small food web' for food, and

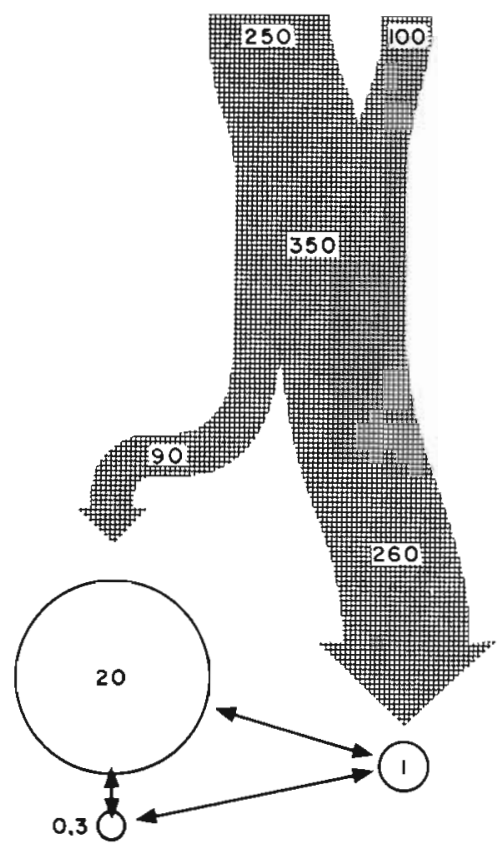

Fig. 2. Carbon flow through tidal flat system. Shaded arrow: flow of detritus input (250) plus autochthonous production (100) towards macrobenthos (90) and into 'small food web' (260). Circles: relative biomass of macrobenthos (20), small food web (1) and macrobenthic predators (0.3). For explanation of arrows connecting circles see text limiting physical factors alone are no longer needed to explain its limited productivity.

Secondly, the 'small food web' - including small macrofauna - offers a substantial source of small food items for juvenile stages of carnivores like shrimps, crabs and fishes. Although the food supply for these carnivores does not seem abundant in terms of biomass, the high productivity by the 'small food web' stands in contrast. We may even have here an explanation for a phenomenon of much wider ecological importance: the fact that different species of carnivores from the open sea use shallow estuarine areas as nursery areas for their youngest benthic stages.

Incorporation of the 'small food web' in the estuarine flow diagram gives a more realistic view of the fate of the large amount of primary food $\left(350 \mathrm{~g} \mathrm{C} \mathrm{m}^{-2} \mathrm{y}^{-1}\right)$ in the benthic system of the Wadden Sea. While in the traditional diagram $90 \mathrm{~g} \mathrm{C} \mathrm{m}^{-2} \mathrm{y}^{-1}$ is consumed by macrobenthos (Fig. 1a) and the remaining $260 \mathrm{~g} \mathrm{C}$ flows into the compartment of the bacteria, in the alternative concept these $260 \mathrm{~g}$ feed the small food web' including, of course, aerobic and anaerobic bacteria. For the tidal flat ecosystem of the Wadden Sea no quantitative estimates on bacterial mineralization in the sediment are available.

Relative data (ETS-studies by Vosjan and OlanczukNeyman, 1977), however, show that the main bacterial decomposition occurs below the aerobic surface layer by sulphate reducing bacteria. When bacterial decomposition alone is used as a balancing item some $75 \%$ of the total organic input in the system would have no other fate than passing almost unchanged through the benthic surface layer on its way to the anaerobic decomposers. This seems an unrealistic view of the mud-flat ecosystem since it assumes an enormous niche on the sediment surface to remain unoccupied. Present studies on the composition of the organic material in the mud-flat sediment (Boon and Haverkamp, 1979) show that a few mm under the mud-flat surface the most easily metabolized compounds have disappeared. The function of anaerobic bacteria, therefore, is most likely that of a last link in the food chains; they thrive on organic material left over in the aerobic part of the 'small food web'.

Of the arrows indicating possible energy flows in the alternative flow diagram, those between the large macrofauna and the 'small food web' compartment actually bring all benthic groups together into one large food web. Although it will be difficult to quantify these two particular energy flows, they both seem to be of an extremely interesting nature. In the first place, there is the question: To what extent do the larger macrobenthic animals feed on bacteria, micro- and meiofauna and even on their own eggs, larvae and newly settled juveniles? Here arises the problem of the 
true trophic function of the larger suspension and detritus feeders in the benthic ecosystem. Secondly, there is the arrow indicating a flow of macrobenthic material into the 'small food web'. As discussed by Thorson (1966), this trophic relationship will mainly concern eggs, larvae, and newly settled young of macrobenthic invertebrates that are exposed during restricted periods of time to a large variety of small predators. It might well be possible, as Thorson stated, that these losses will appear to be one of the key factors in the regulation of abundance and distribution of macrobenthic populations. Thus, apart from possible physical factors (Beukema, 1976) and food competition, discussed in the present paper, mortality of young benthic stages in the 'small food web' may also control macrobenthic production.

\section{LJTERATURE CITED}

Banse, K., Nichols, F. H., May, D. R. (1971). Oxygen consumption by the seabed. III. On the role of the macrofauna at three stations. Vie Millieu I (Suppl. 22): 31-52

Beukema, J. J. (1974). Seasonal changes in the biomass of the macrobenthos of a tidal flat area in the Dutch Wadden Sea. Neth. J. Sea Res. 8: 94-107

Beukema, J. J. (1976). Biomass and species richness of the macrobenthic animals living on the tidal flats of the Dutch Wadden Sea. Neth. J. Sea Res. 10: 236-261

Beukema, J. J. (1977). De rol van bodemdieren in de voedselketens van de zee. Vakbl. Biol. 17: 284-287

Boon, J. J., Haverkamp, J. (1979). Pyrolysis mass spectrometry of a benthic marine ecosystem - the influence of Arenicola marina on the organic matter cycle. Neth. J. Sea Res. 13: $457-478$

Cadée, G. C., Hegeman, J. (1974a). Primary production of phytoplankton in the Dutch Wadden Sea. Neth. J. Sea Res. 8: $240-259$

Cadée, G. C. Hegeman, J. (1974b). Primary production of the benthic microflora living on tidal flats in the Dutch Wadden Sea. Neth. J. Sea Res. 8: 260-291

Cadée, G. C., Hegeman, J. (1979). Phytoplankton primary production, chlorophyll and composition in an inlet of the western Wadden Sea (Marsdiep). Neth. J. Sea Res. 13: $224-241$

Carey, A. G. (1967). Energetics of the benthos of Long Island Sound I. Oxygen utilization of sediment. Bull. Bingham Oceanogr. Coll. 19: 136-144

Davies, J. M. (1975). Energy flow through the benthos in Scottish Sea Loch. Mar Biol. 31: 353-362

Fenchel, T (1969). The ecology of marine microbenthos. IV. Structure and function of the benthic ecosystem, its chemical and physical factors and the microfauna communities with special reference to the ciliated protozod Ophelia 6: 1-182

Fenchel, T (1978). The ecology of micro- and meiobenthos Ann. Rev. Ecol. Syst. 9: 99-121

Fonds, M. (1979). A seasonal fluctuation in growth rate of young plaice (Pleuronectes platessa) and sole (Solea solea) in the laboratory at constant temperatures and a natural daylight cycle. In: Naylor E., Hartnoll, R. G. (eds)
Cyclic phenomena in marine plants and animals. Pergamon Press, New York, pp. 151-156

Gerlach, S. A. (1971). On the importance of marine meiofauna for benthos communities. Oecologia (Berl.) 6: 176-190

Gerlach, S. A. (1978). Food-chain relationships in subtidal silty sand marine sediments and the role of meiofauna in stimulating bacterial productivity. Oecologia (Berl.) 33: 55-69

Günther, B., Guerra, E. (1955). Biological similarities. Acta Physiol. Latinoam. 5: 169

Hemmingsen, A. M. (1960). Energy metabolism as related to body size and respiration surfaces, and its evolution. Rep. Steno meml. Hosp. 9: 1-110

Hulscher, J. B. (1975). Het wad, een overvloedig of schaars gedekte tafel voor vogels? Meded. Werkgr. Waddengebied 1: 57-82

Jonge, V. N. de, Postma $H$. (1974). Phosphorous compounds in the Dutch Wadden Sea. Neth. J. Sea Res. 8: 139-153

Klein Breteler, W M. C. (1976). Settlement, growth and production of the shore crab. Carcinus maenas, on tidal flats in the Dutch Wadden Sea. Neth. J. Sea Res. 10: 354-376

Kuipers, B. R. (1973). On the tidal migration of young plaice (Pleuronectes platessa) in the Wadden Sea. Neth. J. Sea Res. 6: 376-388

Kuipers, B. R. (1977). On the ecology of juvenile plaice on a tidal flat in the Wadden Sea. Neth. J. Sea Res. 11: 56-91

McIntyre, A. D. (1961). Quantitative differences in the fauna of boreal mud associations. J. mar, biol. Ass, U.K. 41: 599-616

Pamatmat, M. M. (1968). Ecology and metabolism of a benthic community on an intertidal sandflat. Int. Revue ges. Hydrobiol. 53: 211-298

Pamatmat, M. M. (1977). Benthic community metabolism: a review and assessment of present status and outlook. In: Coull, B.C. (ed.) Ecology of marine benthos. University of South Carolina Press, S.C., pp. 89-111

Perkins, E. J. (1974). The biology of estuaries and coastal waters, Academic Press, London

Sanders, H. (1960). Benthic studies in Buzzards Bay III. The structure of the soft bottom community. Limnol. Oceanogr 5: $138-153$

Smith, K. L. (1973). Respiration of a sublittoral community. Ecology 54: 1065-1075

Smith, K. L., Burns, K. A., Teal, J. M. (1972). In situ respiration of benthic communities in Castle Harbor, Bermuda. Mar. Biol. 12: 196-199

Steele, J. H. (1974). The structure of marine ecosystems, Blackwell, Oxford

Swennen, C. (1975). Aspecten van de voedselproduktie in de Waddenzee en aangrenzende zeegebieden in relatie met de vogelrijkdom. Vogeljaar 23: 141-156

Thorson, G. (1966). Some factors influencing the recruitment and establishment of marine benthic communities. Neth J. Sea Res. 3: 267-293

Vlas, J. de (1979). Annual food intake by plaice and flounder in a tidal flat area in the Dutch Wadden Sea, with special reference to consumption of regenerating parts of macrobenthic prey. Neth. J. Sea Res. 13: 117-153

Vosjan, J. H. (1975). Ecologische en fysiologische aspecten van bacteriële sulfaatreductie in het waddengebied. Ph. $D$. thesis, Rijks Universiteit Groningen

Vosjan, J. H., Olanczuk-Neyman, K. M. (1977). Vertical distribution of mineralization processes in a tidal sediment. Neth. J. Sea Res. 11: 14-23

Warwick, R. M., Price, R. (1979). Ecological and metabolic studies on free-living nematodes from an estuarine mudflat. Estuar coast. mar Res. 9: 257-271 
Wigley, R. L., Mclntyre, A. D. (1964). Some quantitative comparisons of offshore meiobenthos and macrobenthos south of Martha's Vineyard. Limnol. Oceanogr. 9: 485-493
Wilde, P. A. W. J. de, Berghuis, E. M. (1979). Growth experiments on juvenile lugworms, Arenicola marina, in the laboratory. Neth. J. Sea Res. 13: 487-502.

Topic and authors of this review were suggested by the editor; the review was accepted for printing on February 25,1981 